\title{
A FÖLDRAJZI MOBILITÁS VÁLTOZÓ MINTÁZATAI: Átmeneti elvándorlás, tartós letelepedés és cirkuláris migráció a magyar állampolgárok körében*
}

\section{Ligeti Anna Sára}

\section{ÖSSZEFOGLALÓ}

A migrációt gyakran egyirányú és tartós folyamatként leíró statisztikák egyre kevésbé képesek lépést tartani az ezredfordulót követő globális léptékü, gyorsan változó trendekkel. A ki- és visszavándorlások mérésére használt adminisztratív adatok longitudinális megközelítésü vizsgálatán keresztül azonban lehetőségünk nyílik a magyar állampolgárok migrációs történetének nyomon követésére, az ismétlődő, cirkuláris mozgások azonosítására, valamint a külföldön töltött idő mérésére is. Az adatok alapján a 2010-es évek mobilitási mintázatai egyszerre jellemezhetők tartós külföldi letelepedésekkel és időszakos mozgásokkal. Az évtized során a magyar állampolgárok körében egyre jelentősebbé váltak a "likvid" migrációs mintázatok térnyerését jelző rövidtávú és ismétlődő vándorlások, melyek elsősorban nem a magasabb társadalmi-gazdasági státuszú, hanem az ipari és szolgáltatói szektorban dolgozók időszakos munkavállalási stratégiáit jellemzik. Az évtized elején, a kivándorlások intenzív szakaszában távozók fele máig nem tért vissza, a külföldön élő magyarok számának folyamatos növekedése pedig az évtized második felétől kezdve lehetővé tette a folyamatos visszaáramlásokat a hosszabb idő óta külföldön élők köréből is. Ezzel párhuzamosan az évtized végére Nagy-Britannia sokat vesztett népszerüségéből a kivándorlók között, így mostanra Németország és Ausztria tekinthetők a legfőbb célországoknak. 
Tárgyszavak: Földrajzi mobilitás, kivándorlás, visszavándorlás, cirkuláris migráció

Ligeti Anna Sára, Központi Statisztikai Hivatal, Pécsi Tudományegyetem

E-mail: Anna.Ligeti@ksh.hu

\section{BEVEZETÉS}

A nemzetközi vándorlás kutatásának múlt században intézményesült fogalmi keretei és módszertani eszköztára - amely a migrációt leginkább egyirányú folyamatként írja le - egyre kevésbé képes lépést tartani az ezredfordulót követő globális léptékủ, gyorsan változó migrációs trendekkel és annak különféle formáival. Mára már világossá vált, hogy a migráció nem fogható fel csupán hosszú távú, akár életre szóló döntések következményeként, melynek során egy személy elhagyja születési országát, hogy azután egy másik országban éljen (esetleg a folyamatot megfordítva, bizonyos időt követően hazaköltözzön), hanem akár rövidebb távú oda-vissza mozgások, cirkulációk, „multilokációk” összességeként is jellemezhető. Mivel a folyamatosan alakuló mintázatok sokfélesége nem írható le többé a hagyományos fogalmakkal, így helyesebb volna ezeket a tágabb értelmű földrajzi mobilitás, esetleg „likvid migráció” névvel illetni (Melegh, 2011; Engbersen and Snel, 2013; Bálint et al., 2017; de Haas et al., 2020).

A jelenkori mobilitási mintázatok és mozgások szerkezetének átfogó ismerete elsősorban a migráció következményeinek jobb megértéséhez volna elengedhetetlen, melyek társadalmi-gazdasági és demográfiai szempontokból is különbözőek lehetnek attól függően, hogy az országhatárokon átivelő mozgások mennyire mondhatók egyirányúnak és hosszú távúnak. A tartós külföldi letelepedéssel járó kivándorlással ellentétben - amely a kibocsátó országok számára a fiatalabb népesség és a magasan képzett munkaerő elvesztését jelentheti - a rövidtávú, esetleg cirkuláris, ismétlődő formák jobban reagálnak a munkaerő-piaci igényekre és kilengésekre, valamint nem járnak súlyos integrációs terhekkel a befogadó országok számára sem (Agunias, 2006; Triandafyllidou, 2013).

Magyarország Európai Uniós csatlakozását követő években a szabad mozgás és tartózkodás joga nem csak a hosszabb távra külföldre költözők számára nyitott eddig nem tapasztalt lehetőségeket, de olyan mobilitási formáknak is teret engedett, melyek az azt megelőző jogi környezetben jóval nehezebben valósulhattak meg. Az EU csatlakozást követő években fokozatosan feloldott munkaerő-piaci korlátozásokhoz és a 2008-as gazdasági válság hatásaihoz köthetően 
az évtized elejét a magyar állampolgárok intenzív elvándorlása jellemezte, amely az évtized közepére csökkenni kezdett. Ezzel párhuzamosan a visszavándorlások száma folyamatosan emelkedett 2010 és 2020 között, melynek eredményeként az utóbbi években a visszavándorlások száma megelőzte a kivándorlásokét (Blaskó és Gödri, 2014, Gödri, 2018; Hárs, 2020; KSH, 2021).

Jelen tanulmány a hazai adminisztratív adatok longitudinális megközelítésű vizsgálatán keresztül három kérdéskört jár körül: (1) az évtized folyamán vándorló magyarokra milyen mértékben jellemzőek a rövidtávú és ismétlődő mozgások, amelyek a „likvid” mobilitási formák jelenlétére utalnak? (2) Közel tíz év távlatából hogyan értékelhető a 2010-es évek elején megugró kivándorlási trend? Tartósan elhagyták-e az országot azok, akik az évtized elején kivándoroltak, vagy azóta hazatértek? (3) Minek köszönhető az elmúlt évek intenzív visszavándorlása, kik és mennyi idő után térnek haza?

\section{AZ ADATOKRÓL}

A fenti kérdésekre a Nemzeti Egészségbiztosítási Alapkezelő (NEAK) TAJ nyilvántartásának két adminisztratív alrendszerének adatai alapján adhatunk válaszokat. Az első - és jóval jelentősebb, a felhasznált adatok közel háromnegyedét tartalmazó - állományban azok szerepelnek, akik több-kevesebb időre társadalombiztosítási jogviszonyt létesítenek egy másik országban, a másodikban pedig azok, akik a külföldre költözésükkor megszüntetik a hivatalos magyarországi lakcímüket. Mindkét állományról elmondható, hogy segítségükkel kizárólag a bennük szereplő magyar állampolgárok regisztrált, adott időszakra vonatkozó ki- és visszavándorlásaira nézve vonhatunk le következtetéseket. Tehát belölük csupán a vándorlás folyamatmutatói, úgynevezett flow típusú adatok állíthatók elő, így a külföldön élő magyar állampolgárok számának - stock adatainak - megállapítására nem alkalmasak.

Bár kivándorláskor - pontosabban egy külföldi társadalombiztosítási jogviszony létesítésekor - jogszabályi kötelezettség’ a magyarországi jogviszony szüneteltetését bejelenteni a hazai egészségbiztosítónál (hazatérés esetén pedig újra aktiválni azt) mégis feltételezhető, hogy ennek a regisztrációs kötelezettségnek sokan nem tesznek eleget. Azzal kapcsolatban azonban, hogy pontosan hányan maradnak ki a regiszterből, csupán feltételezésekkel élhetünk. Nem rendelkezünk pontos információkkal az alulbecslés mértékéről, sem annak időbeli változásáról, illetve

1997. évi LXXXIII. törvény a kötelező egészségbiztosítás ellátásairól, az Európai Parlament és a Tanács 883/2004/EK rendelete a szociális biztonsági rendszerek koordinálásáról. 
arról, hogy mely népességcsoportokat jellemez inkább a regisztrációs hajlandóság hiánya. Mivel jelenleg nem létezik olyan adatforrás, amely pontos képet festene a kiés visszavándorlók teljes számáról és összetételéről, így nincsenek olyan adataink, amelyek viszonyítási alapot jelenthetnének a lefedettség meghatározásához.

Az összevetéshez leggyakrabban használt tükörstatisztikák jelentősen több magyar állampolgárságú bevándorlót tartanak számon az egyes országokban, mint amennyit a magyarországi hatóságok kivándorlóként regisztrálnak. ${ }^{2}$ Figyelembe kell vennünk azonban az egyes statisztikai rendszerek közötti módszertani és definíciós különbségeket is. ${ }^{3}$ Továbbá szintén jelentős eltérések adódhatnak abból, hogy egy adott országba bevándorló magyar állampolgárok nemcsak hazánkból, de a szomszédos országokból is érkezhetnek (Csányi et al., 2021). Fontos emellett szem előtt tartani az adminisztratív regiszterekbe való be- és kilépések egyfajta aszimmetriáját is. Mivel legtöbbször szigorúbb kényszerekkel és nagyobb előnyökkel jár egy regiszterbe való bekerülés (például a közszolgáltatások elérése tekintetében), mint az abból való kikerülés, általánosságban elmondható, hogy a bevándorlók regisztrációs hajlandósága magasabb a kivándorlókénál. Ez azonban hatással lehet a tükörstatisztikák lefedettségére is (Monti et al., 2019; Willekens, 2019; Csányi et al., 2021).

Kérdéses az is, hogy a hazai nyilvántartásokból következő lefedettségi hiány azonos módon érinti-e a népesség különböző csoportjait, és időben változik-e annak mértéke. Bár e kérdések tekintetében is sokszor csak feltételezésekkel élhetünk, látható, hogy az elmúlt évtizedben a különböző adatforrások a ki- és visszavándorlók demográfiai összetételét és a trendek alakulását illetően is hasonló képet festenek (Gödri, 2018). Így nem rajzolódnak ki olyan demográfiai csoportok, melyek a vizsgált populációhoz viszonyítva jóval kisebb vagy nagyobb arányban regisztráltak. A lefedettség időbeni változását illetően szintén nem rendelkezünk pontos információkkal. Annak ellenére, hogy a regisztrációs kötelezettség bevezetése óta nem történt jogszabályi változás, könnyen elképzelhető, hogy annak alkalmazása időben változik (mind Magyarországon, mind a fogadó országokban), vagy a bevezetés óta eltelt idő alatt más okokból módosul az érintettek regisztrációs hajlandósága (például az ezzel kapcsolatos kötelezettségek egyre jobban beépülnek a köztudatba).

\footnotetext{
${ }^{2}$ Ameddig 2019-ben a magyarországi hivatalos statisztikai adatok 21 ezer kivándorlót mutattak, az Eurostat tükörstatisztikáiban ugyanakkor 21 ezer magyar állampolgárságú bevándorló jelent meg két fontos célország, Németország és az Egyesült Királyság adatai nélkül (KSH, 2021; Eurostat, 2021).

${ }^{3}$ Németországban például az általános európai gyakorlattól eltérően nem a szokásos lakóhely szerinti népességdefiníciót ("usually resident population") alkalmazzák, hanem a tágabb értelmü lakóhely szerint regisztrált népesség ("registered residence population") meghatározást (Eurostat, 2019).
} 
A fent említett számos bizonytalanság ellenére a NEAK nyilvántartása több szempontból is kivételes lehetőségeket rejt, és olyan nézőpontú elemzést tesz lehetővé, melyre más adatforrások nem alkalmasak. Ez főként annak köszönhető, hogy az adminisztratív adatok hosszabb időtávra visszanyúlva teszik lehetővé a bennük szereplő magyar állampolgárok migrációs történetének nyomon követését, valamint lehetőséget nyújtanak a ki- és visszavándorlás különböző definícióinak alkalmazására.

Fontos megjegyezni, hogy bár a magyar állampolgárok ki- és visszavándorlására vonatkozó hivatalos statisztikák szintén a NEAK adminisztratív adatain alapulnak (KSH, 2021), az eltérő definíciók és adatkörök alkalmazásából, valamint a különböző nézőpontú megközelítésekből fakadóan jelen elemzés eredményei nagyságrend és gyakran trendek szempontjából sem vethetők össze azokkal. A két különböző megközelítésü adatfeldolgozás legfőbb eltéréseit az 1. táblázat foglalja össze.

1. táblázat: A magyar állampolgárok ki- és visszavándorlására vonatkozó hazai hivatalos statisztikák és a jelen longitudinális elemzés közötti legföbb különbségek

\begin{tabular}{|c|c|c|}
\hline & Hazai hivatalos statisztikák & Longitudinális elemzés \\
\hline $\begin{array}{l}\text { A vizsgálat } \\
\text { megközelítése és } \\
\text { időkerete }\end{array}$ & $\begin{array}{l}\text { Keresztmetszeti, az adott naptári } \\
\text { évben regisztrált mozgások. }\end{array}$ & $\begin{array}{l}\text { Longitudinális, az állományban } \\
\text { szereplő személyek migrációs } \\
\text { történetének nyomon követése } \\
\text { 2010-2020 között. }\end{array}$ \\
\hline $\begin{array}{l}\text { Kivándorlók } \\
\text { meghatározása }\end{array}$ & $\begin{array}{l}\text { Azok a magyar állampolgárok, akik } \\
\text { (ténylegesen vagy terveik szerint) } \\
\text { legalább } 12 \text { hónapra hagyják el } \\
\text { Magyarországot. }\end{array}$ & $\begin{array}{l}\text { Azok a magyar állampolgárok, akik } \\
\text { legalább } 3 \text { hónapos magyarországi } \\
\text { tartózkodást követően } \\
\text { legalább } 3 \text { hónapra elhagyták } \\
\text { Magyarországot. }\end{array}$ \\
\hline $\begin{array}{l}\text { Visszavándorlók } \\
\text { meghatározása }\end{array}$ & $\begin{array}{l}\text { Azok a Magyarországon született } \\
\text { magyar állampolgárok, akik } \\
\text { legalább } 12 \text { hónapos külföldi } \\
\text { tartózkodás után visszatérnek } \\
\text { Magyarországra. }\end{array}$ & $\begin{array}{l}\text { Azok a magyar állampolgárok, } \\
\text { akik legalább } 3 \text { hónapos } \\
\text { külföldi tartózkodást követően } \\
\text { legalább } 3 \text { hónapra visszatérnek } \\
\text { Magyarországra. }\end{array}$ \\
\hline $\begin{array}{l}\text { Az adatokban } \\
\text { megjelenő } \\
\text { személyek }\end{array}$ & $\begin{array}{l}\text { Azok a magyar állampolgárok, akik } \\
\text { társadalombiztosítási jogviszonyt } \\
\text { létesítenek egy másik országban. }\end{array}$ & $\begin{array}{l}\text { Azok a magyar állampolgárok, } \\
\text { 1. akik társadalombiztosítási } \\
\text { jogviszonyt létesítenek egy másik } \\
\text { országban. } \\
\text { 2. akik megszüntetik a hivatalos } \\
\text { magyarországi lakcímüket }{ }^{4} \text {. }\end{array}$ \\
\hline
\end{tabular}

Forrás: saját szerkesztés

\footnotetext{
${ }^{4}$ Mivel ez az állomány nem tartalmaz információkat a külföldi tartózkodás országára vonatkozóan, valamint a benne szereplők magyarországi lakóhelyei tekintetében is alacsony kitöltöttség jellemzi, így területi szintű adatok előállitására nem alkalmas, ebből következően pedig a hivatalos statisztika számára nem használható.
} 
Az eltérés elsősorban abból fakad, hogy ameddig jelen elemzés longitudinális ${ }^{5}$ vizsgálatra épül, a hivatalos statisztikák ki- és visszavándorlási adatai keresztmetszeti adatok. Ezáltal az általuk rajzolt trendekben csak az adott évi mozgások jelennek meg, amelyekből nem derül ki, hogy összesen hány személy vesz részt e folyamatokban és, hogy ideiglenes elmozdulásokról vagy inkább tartós letelepedésekről van szó. Ezzel szemben a longitudinális adatok lehetővé teszik a migrációs folyamatokban résztvevő személyek nyomon követését, így választ kaphatunk olyan kérdésekre is, hogy a kivándorlók mennyi időt töltöttek külföldön, hányszor és milyen országokba vándoroltak. Emellett a longitudinális megközelítés az adatbázisokban előforduló hibás rögzítések kiszürésének és az adathiányok részleges pótlásának módszertani lehetőségeit egyaránt kiszélesíti. ${ }^{6}$ Fontos különbség, hogy ameddig a keresztmetszeti vizsgálatok csupán egy adott évre vonatkoznak, addig a longitudinális megközelítéshez egy hosszabb időintervallum vizsgálatára van szükség, ezért az adatoknak bizonyos időtávra visszamenőlegesen is rendelkezésre kell állniuk. Az itt felhasznált adatok esetében ez legfeljebb tízéves periódust jelenthet, mivel a NEAK TAJ nyilvántartásának ki- és visszavándorlásra vonatkozó adatai 2010-től állnak rendelkezésünkre.

A longitudinális megközelítés mellett ugyancsak alapvető különbséget jelent az eltérő definíciók alkalmazása. Bár a hivatalos statisztikai adatok a szokásos lakóhely szerinti népességdefinícióra épülnek, - vagyis csak olyan demográfiai eseményeket tekintenek nemzetközi vándorlásnak, melyek során a külföldi tartózkodás időtartama ténylegesen vagy a vándorló személy tervei szerint eléri a 12 hónapot (KSH, 2021) - az adatforrás lehetővé teszi, hogy ennél tágabban értelmezzük a migráció fogalmát. Annak érdekében, hogy minél jobban meg tudjuk ragadni az elmúlt évtized változásait és minél pontosabb képet kaphassunk a magyarok vándorlási mintázatairól, a hivatalos migráció meghatározást kibővítve a tágabb értelmű földrajzi mobilitást vizsgáljuk, így a rövidtávú, legalább 3 hónapos tartózkodáshoz kötött mozgásokat is beemeljük az elemzési körbe?

\footnotetext{
${ }^{5}$ Longitudinális adatokat ugyanazon elemzési egységektől, például egyénektől vagy háztartásoktól gyüjtünk egy meghatározott időn keresztül, így a vizsgált jelenségek időbeni változásait is nyomon tudjuk követni (UNECE, 2020). ${ }^{6}$ Ebben az esetben minden rögzített ki- és visszavándorlási dátum összevethető a személy korábbi vándorlási eseményeivel, így láthatóvá válnak különböző rögzitési hibák és adathiányok. Például, ha két kivándorlás között hiányzik a visszavándorlás dátuma vagy a visszavándorlási dátum korábbi, mint a kivándorlás ideje.

${ }^{7}$ A továbbiakban a migráció, vándorlás és mobilitás szavakat szinonimaként használom a legalább 3 hónapos külföldi tartózkodásokra vonatkozóan, valamint az elemzéshez felhasznált adminisztrativ adatokban regisztrált személyeket tekintem ki-és/vagy visszavándorlóknak.
} 
Az elemzéshez felhasznált adatok összesen 507 ezer kivándorlási és 202 ezer visszavándorlási eseményt foglalnak magukba (melyből 430 ezer kivándorlás és 198 ezer visszavándorlás esik 2010 és 2020 közé). Ezek évenkénti megoszlását a 2. táblázat foglalja össze.

2. táblázat: Kivándorlások és visszavándorlások száma, 2010-2020

\begin{tabular}{ccccc} 
Év & \multicolumn{2}{c}{$\begin{array}{c}\text { Kivándorlások száma } \\
\text { Ebből első } \\
\text { kivándorlás }\end{array}$} & $\begin{array}{c}\text { Visszavándorlások száma } \\
\text { Összesen }\end{array}$ & $\begin{array}{c}\text { Eből első } \\
\text { visszavándorlás }\end{array}$ \\
\hline 2010 & 16745 & 16374 & 2940 & 2825 \\
2011 & 27175 & 26336 & 4614 & 4392 \\
2012 & 42428 & 40143 & 8669 & 8146 \\
2013 & 44934 & 41921 & 11229 & 10322 \\
2014 & 49483 & 44996 & 14949 & 13517 \\
2015 & 51088 & 45259 & 19018 & 16930 \\
2016 & 52756 & 44961 & 20325 & 17598 \\
2017 & 47209 & 40102 & 29182 & 25543 \\
2018 & 42917 & 35351 & 30499 & 26523 \\
2019 & 37213 & 29457 & 29947 & 25639 \\
2020 & 18146 & 13775 & 26157 & 21140
\end{tabular}

Forrás: saját szerkesztés a NEAK TAJ adatai alapján.

\section{A HIVATALOS STATISZTIKA SZÁMÁRA LÁTHATATLAN MOBILITÁSI FORMÁK: RÖVID TÁVÚ MIGRÁCIÓ ÉS CIRKULARITÁS}

Annak ellenére, hogy hazánkban is egyre relevánsabbá válik a leginkább átmenetiséggel és folyamatos változásokkal jellemezhető mintázatok vizsgálata, az Európai Uniós és hazai jogi környezet által formált hivatalos statisztika eszköztára a mai napig nem terjed ki az ehhez szükséges két alapvető kritérium, a rövid távú mozgások és az ismétlődő formák mérésére. ${ }^{8}$ A rövid távú és cirkuláris mobilitások így a hivatalos statisztikákban vagy láthatatlanok maradnak, vagy csak részben jelennek meg az olyan statisztikai adatokban, melyek a hivatalos

\footnotetext{
${ }^{8}$ Nem állíthatjuk azonban, hogy ezek szükségességét nem ismerték volna fel a hivatalos statisztika területén. Amellett, hogy a hivatalos migráció definíció alapját jelentő ENSZ ajánlás (UN, 1998) kitér a rövid távú migráció meghatározására (amely egy évnél rövidebb, de három hónapot meghaladó külföldi tartózkodást feltételez), az utóbbi években különböző kísérletek születtek többek között a munkavállalási mobilitás és a cirkuláris migráció meghatározására, valamint a migráció longitudinális módszerekkel történő vizsgálatára is (UNECE, 2016; 2018; 2020).
} 
migrációs definícióktól eltérő meghatározásokat követnek (például munkaerőpiaci statisztikákban, vagy egyes országok tükörstatisztikáiban).

Kevés adat áll rendelkezésünkre azonban arról, hogy hogyan alakul a rövid távú és ismétlődő mobilitásokban résztvevők száma és aránya a nemzetközi vándorlási folyamatokba bekapcsolódók körében. Valóban egyre jobban terjednek ezek a formák, melyek a komplexebb, "likvid” migrációs mintázatok térnyerését jelzik? Mely társadalmi csoportok választják leginkább az átmeneti mozgásokat? Az előnyösebb társadalmi-gazdasági helyzetben lévők kiváltsága az a transznacionális életforma, amelyben a nemzetközi határok elmosódnak, a nyelvi és kulturális akadályok pedig nem szabnak gátat a külföldi munkavállalás és tanulás előtt? Vagy éppen ellenkezőleg, az előnytelenebb munkaerő-piaci pozícióban lévők stratégiája lenne a magasabb jövedelmek eléréséhez?

Az adatok alapján úgy tünik, az első kérdésre egyértelmü választ adhatunk: a vizsgált évtized során megfigyelhető változások közül valóban az egyik legszembetűnőbb a rövid távú és cirkuláris mobilitási formák fokozatos térnyerése. Ameddig 2010-ben a kivándorlások csupán 9\%-a végződött egy éven belüli visszatéréssel, addig ez az arány 2019-ben már 21\% volt. Meg kell jegyezni azonban, hogy bár a rövid távú mobilitások aránya növekedett a migrációs folyamatokban résztvevők körében, számuk 2017-től csökkenésnek indult, amely a kivándorlások számának általános visszaesésével magyarázható.

Mivel az ismétlődő, cirkuláris formák azonosításához nem csupán egy időpont, hanem sokkal inkább egy időszak vizsgálatára van szükség, ezért a rendelkezésre álló 10 éves időtáv a hosszabb idősoros elemzéséhez nem elegendő. ${ }^{9}$ Ennek ellenére az utóbbi évek (és az ezeket megelőző 8 éves időperiódusok) alapján már levonhatunk óvatos következtetéseket a cirkuláris formák terjedésére vonatkozóan, hiszen 2018-ban a kivándorlók 17\%-a, 2019-ben 20\%-a, 2020ban pedig már 23\%-a töltött hosszabb-rövidebb időt külföldön az adott évet megelőzően is (1. ábra). Nem állithatjuk azonban, hogy a cirkuláris migránsok folyamatos mozgásban vannak, mivel többségük (75-80\%) csupán kétszer élt külföldön a vizsgált években. Látható emellett, hogy a cirkuláris migránsokat többségében rövid távú mozgások jellemzik, így a két mobilitási típus jelentős átfedésben van egymással: az évtized során előforduló, néhány hónapos külföldi tartózkodások 43\%-a egy cirkuláris lánchoz sorolható, míg az 1 éves tartózkodások 28\%-a, a 2 éves tartózkodásoknak pedig 20\%-a mondható ismétlődőnek.

\footnotetext{
${ }^{9}$ Bár az ENSZ és az Eurostat hivatalos ajánlása alapján a cirkuláris migráció méréséhez 10 éves időperiódus vizsgálatára volna szükség (UNECE, 2016), esetünkben - mivel a vizsgált adatok összesen 10 évet ölelnek fel - azonban csak a 2020-as év adatai lennének alkalmasak a definíció pontos betartására. Így ebben az esetben a meghatározást némileg módosítva, a 2018-2020-as évek mozgásait megelőző 8 éves periódust vizsgáltuk.
} 
1. ábra: A rövid távú (legalább 3 hónapos, de 12 hónapnál rövidebb) külföldi tartózkodások és a cirkuláris mozgások aránya az adott évi kivándorlások körében, 2010-2019

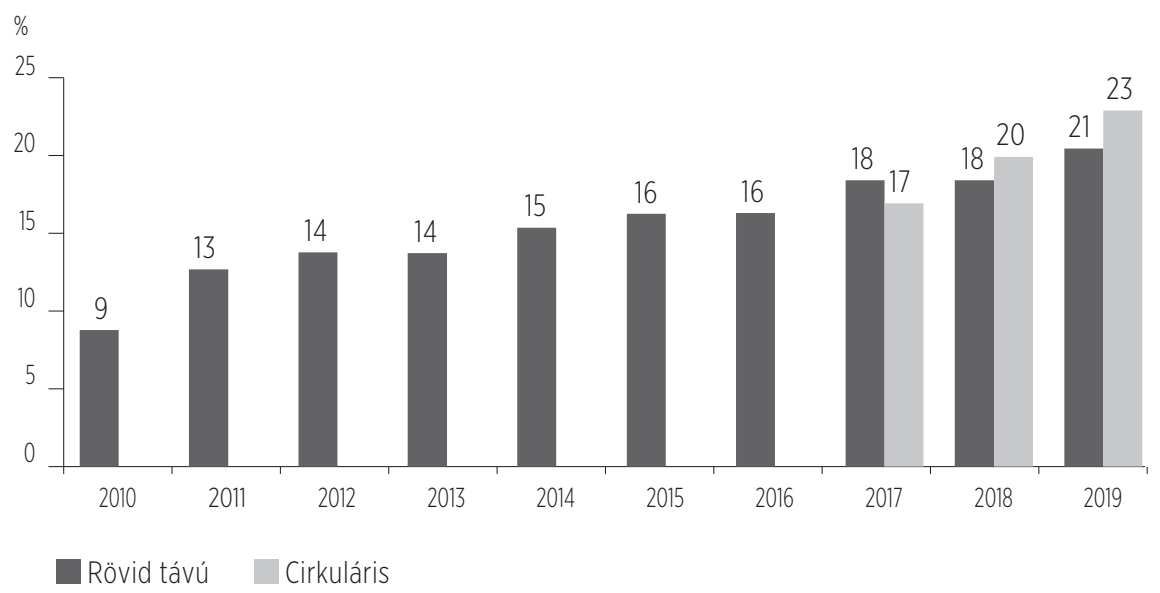

Forrás: saját szerkesztés a NEAK TAJ adatai alapján.

Természetesen a rövid távú és cirkuláris mozgásokban kulcsszerepet játszik a földrajzi távolság, ezáltal Ausztria különösen népszerü az ilyen típusú mobilitási formákat választók körében. 2019-ben az egy évnél rövidebb időtartamú kivándorlások fele (49\%) Ausztriába irányult, miközben az Egyesült Királyságba és Németországba való vándorlás jelentősen visszaszorult. Előbbi folyamatosan csökkenve, utóbbi sokkal inkább az évtized második felétől kezdve (2015-ben a rövid távra kivándorlók 29\%-a választotta Németországot, 2019-ben azonban már csak 21\%) (1. melléklet).

Látható az is, hogy a rövid távú és cirkuláris mozgásokban nagyobb valószínűséggel vesznek részt idősebb korcsoportok: a 2018-2020 között visszavándorlók összesen 24\%-a volt 40 évnél idősebb, a néhány hónapos külföldi tartózkodást követően hazatérők közel harmada (31\%), a cirkuláris migránsoknak pedig 37\%-a tartozott szintén ebbe a korcsoportba. Megfigyelhető továbbá, hogy a rövid távú mobilitás egyre inkább az idősebb korcsoportok migrációs stratégiájává válik az évtized folyamán: míg 2010-ben a rövid távra kivándorlók 14\%-a volt 40 éven felüli, addig 2019-ben már 32\%-a (2. melléklet).

Bár a felhasznált adminisztratív adatok nem igazán megfelelőek arra, hogy a fenti jelenségek társadalmi összetételét mélyebben megvizsgáljuk, azonban az utóbbi években visszatérők esetében lehetőségünk nyílik a gazdasági akti- 
vitás és foglalkozás vizsgálatára, ${ }^{10}$ amely alapján bizonyos következtetéseket vonhatunk le a rövid távú és cirkuláris mobilitásban résztvevők társadalmi státuszát illetően. Látható, hogy ezek a migrációs formák kevéssé jellemzőek a magasabb iskolai végzettségü, szellemi foglalkozásokban dolgozókra, sokkal inkább tekinthető az alacsonyabb társadalmi-gazdasági státuszú, valamint az ipari és szolgáltatási szektorban dolgozók időszakos migrációs és munkavállalási stratégiájának. Míg az egyszeri, néhány hónapos kivándorlás leginkább a szakmunkás vagy annál alacsonyabb iskolai végzettséget igénylő foglalkozásokban dolgozókra jellemző, addig a cirkuláris, ismétlődő mobilitási formákban résztvevők körében - feltehetően jelentős részben a turizmus szezonális jellegének köszönhetően - a kereskedelmi és szolgáltatási szektorban dolgozók aránya jelentősebb. Főként a cirkuláris mobilitásokba bekapcsolódók esetében az „egyéb jogcímü”

2. ábra: A 2018-2020 között rövid távú külföldi tartózkodást és cirkuláris migrációt követően viszszavándorlók gazdasági aktivitása

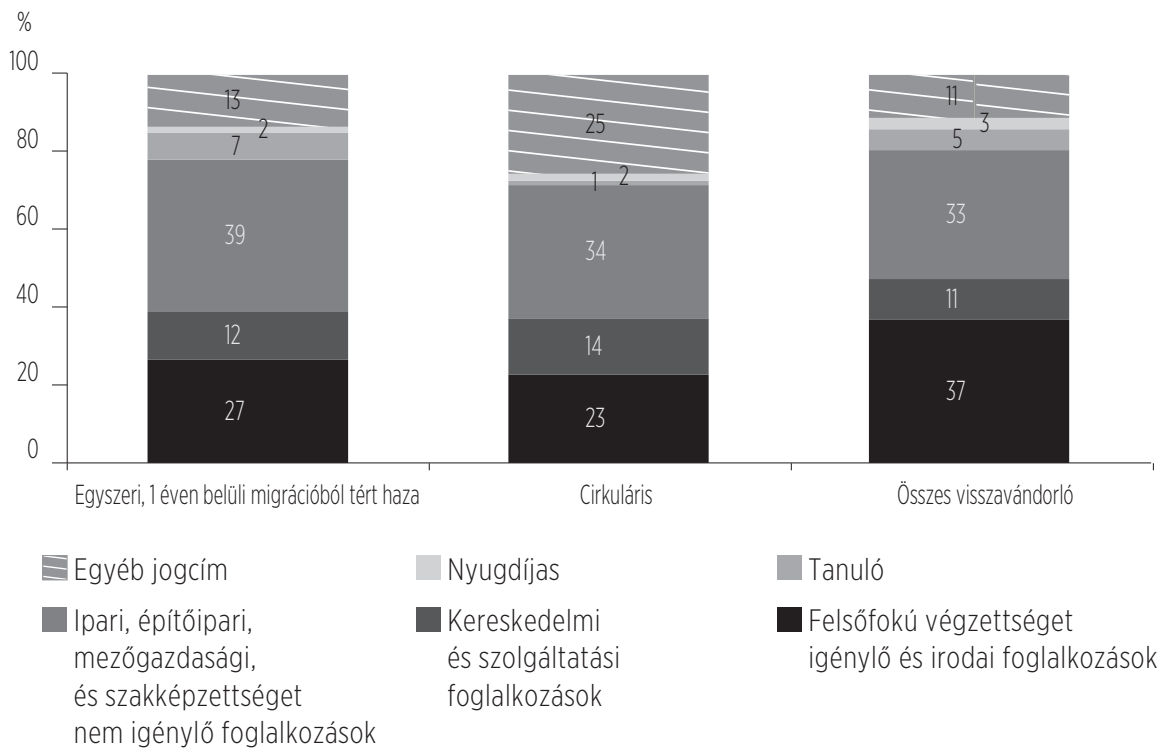

Forrás: saját szerkesztés a NEAK TAJ adatai alapján. N=43 124

\footnotetext{
${ }^{10}$ A rendelkezésre álló adatokból az egészségbiztositás jogosultságának jogcíme alapján következtethetünk az utolsó visszavándorlást követően Magyarországon regisztrált gazdasági aktivitásra és foglalkozásra. Ebben az esetben azonban jelentős adathiánnyal (48\%) kell számolnunk. Ez főként annak köszönhető, hogy azok, akik a hazatérésük bejelentésekor nem voltak biztosítottak (pl. nem állnak munkaviszonyban) vagy egészségügyi szolgáltatásra nem jogosultak (pl. nem nyugdíjasok, tanulók, GYES-en lévők), azonban a társadalombiztositás szabályai kiterjednek rájuk, egészségügyi szolgáltatási járulékukat saját maguk fizetik. Ezen személyek gazdasági aktivitásával kapcsolatban nem rendelkezünk további információkkal.
} 
visszavándorlók jelentős aránya szintén az alacsonyabb társadalmi-gazdasági státuszra utalhat, hiszen ide föként olyanok tartoznak, akik a hazatérésüket követően rokkantsági, munkanélküli ellátásban, fogyatékossági támogatásban vagy gyermekgondozási segélyben részesültek. A tanulók főként a rövid távú mobilitásban résztvevők között jelennek meg (feltehetőleg Erasmus vagy más felsőoktatási programok résztvevőjeként), ez azonban - mivel a vizsgált státusz az utolsó visszavándorlás pillanatára vonatkozik - nem feltétlenül jelenti, hogy például a cirkuláris migrációban résztvevők korábban nem tanultak külföldön (2. ábra).

Látható tehát, hogy - bár a hivatalos statisztikai adatokban ezek nem jelennek meg, - az ideiglenes és ismétlődő elmozdulásokkal jellemezhető mobilitási formák egyre jelentősebbé válnak. Ezzel párhuzamosan (azonban, ahogy később látni fogjuk, nem kizárólag ennek köszönhetően) Ausztria földrajzi közelsége is felértékelődni látszik. A rövidtávú és cirkuláris mobilitás formák jelentős részben az ipari és szolgáltatási szektorban dolgozókhoz köthető és az ilyen típusú mozgások terjedésével a nemzetközi vándorlási folyamatokba bekapcsolódók társadalmi összetétele is átalakulhat.

\section{ELVÁNDORLÁS EGY ÉVTIZED TÁVLATÁBÓL: A 2010-2013 KÖZÖTT KIVÁNDORLÓK MIGRÁCIÓS TÖRTÉNETE}

Az EU csatlakozást követően a magyarok kivándorlása a régió más országaihoz képest megkésve indult, és bár nagyságrendjét tekintve meg sem közelítette például a romániai vagy lengyelországi elvándorlást, gyorsan növekedett a 2010-es évek első felében (Hárs, 2020). Az osztrák és német munkaerő-piac csak 2011-ben nyitotta meg kapuit a magyarok előtt, ezért a 2010-ben kivándorlók elsődleges célországát még az Egyesült Királyság jelentette. Az Ausztriába és főként Németországba vándorlók aránya 2011 után jelentősen megugrott, ezzel együtt azonban az Egyesült Királyság lassan, de fokozatosan vesztett előnyéből. A NEAK TAJ nyilvántartásában megjelenő kivándorlók az évtized elején, 2010 és 2013 között közel azonos arányban vándoroltak Németországba (29\%) és az Egyesült Királyságba (28\%), míg 20\% Ausztriába, 22\% pedig valamelyik másik uniós országba költözött, illetve a vizsgált időszakban kivándorlók csupán 1\%-a indult az EU-n kívülre.

A magyarok elvándorlásával foglalkozó elemzések többsége az emlitett trend tartós fennmaradására számított, a külföldön élők körében végzett kér- 
dőíves kutatások pedig mérsékelt visszavándorlási potenciálról számoltak be (Moreh, 2014; Blaskó és Gödri, 2014; Hárs, 2018; Hárs, 2020). Kevés adat állt azonban rendelkezésre arról, hogy a kivándorlók milyen arányban térnek haza ténylegesen. Az OECD becslése alapján a kivándorlók 20-50\%-a a kivándorlást követő öt évben hazatér vagy továbbköltözik egy másik országba, azonban a visszavándorlások arányát erőteljesen alakitja az életkor és az iskolai végzettség, valamint a külföldön eltöltött idő (OECD, 2008). Horváth Ágnes (2016) a hazai adminisztratív adok és tükörstatisztikák alapján a 2008-as válságot követően visszatérők arányát 25 és 42\% közé tette.

De vajon hogyan alakultak a hazatérések az ezt követő időszakban, és hogyan értékelhető a 2010-es évek elején kivándorló magyarok migrációs története az évtized végén? A kivándorlási hullám elején távozó, az adatbázisban megjelenő közel 130 ezer ember valóban új életet kezdett külföldön vagy csupán időszakos külföldi munkavállalásról, kalandvágyról volt szó?

Közel egy évtized távlatából visszatekintve úgy tűnik, a vizsgált időszak elvándorlásai valóban tartósnak mondhatók: a 2010 és 2013 között kivándorlók fele 2020 végéig (még) nem költözött vissza Magyarországra, további 14\% pedig egy egyszeri hosszabb idejü, legalább 5 éves külföldi tartózkodást követően tért haza. A rövidebb távú mozgásokban résztvevők aránya jóval alacsonyabb, mint a későbbi években, és összesen 16\%-ra volt jellemző, hogy a visszatérést követően újra kivándorolt, esetleg több alkalommal is (3. ábra).

\section{3. ábra: A 2010-2013 között kivándoroltak mobilitási mintázatai}

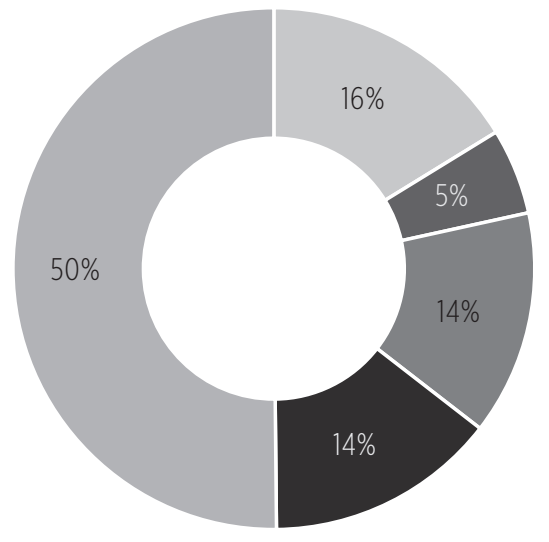

Cirkuláris mobilitás

1 évnél rövidebb külföldi tartózkodást követő egyszeri visszavándorlás

1-4 év külföldi tartózkodást követő egyszeri visszavándorlás

Legalább 5 évi külföldi tartózkodást követő egyszeri visszavándorlás

Egyszeri kivándorlás 
A három fő célország közül az Egyesült Királyságba vándorlókra volt leginkább jellemző a tartós külföldön maradás: az ide költözők 51\%-a 2020 végéig még nem tért vissza, 19\%-uk pedig 5 évi tartózkodást követően (vagyis többségében 2016 után, a visszavándorlási trend megugrásakor) költözött haza. Az Egyesült Királyságba költözők mobilitási mintázataira leginkább a Németországba és az EU-n kívülre vándorlók hasonlítanak, bár Németországban magasabb a rövid távú és ismétlődő mozgások aránya, az EU-n kívüli országokban pedig a tartós migrációs formák. A földrajzi közelség miatt nem meglepő, hogy a vizsgált kivándorlási célterületek közül Ausztria volt az egyetlen, ahol a cirkuláris és a rövid távú mozgásokban résztvevők száma megelőzte a tartósan letelepedőkét. Ám utóbbi aránya az Ausztriába vándorlók körében is jelentős, összesen 45\% volt (31\%-ról mondható el, hogy az évtized eleji kivándorlást követően nem tért haza, további 14\% pedig legalább 5 éves tartózkodást követően vándorolt vissza) (4. ábra).

\section{4. ábra: A 2010-2013 között kivándoroltak mobilitási mintázatai a föbb célországok szerint}

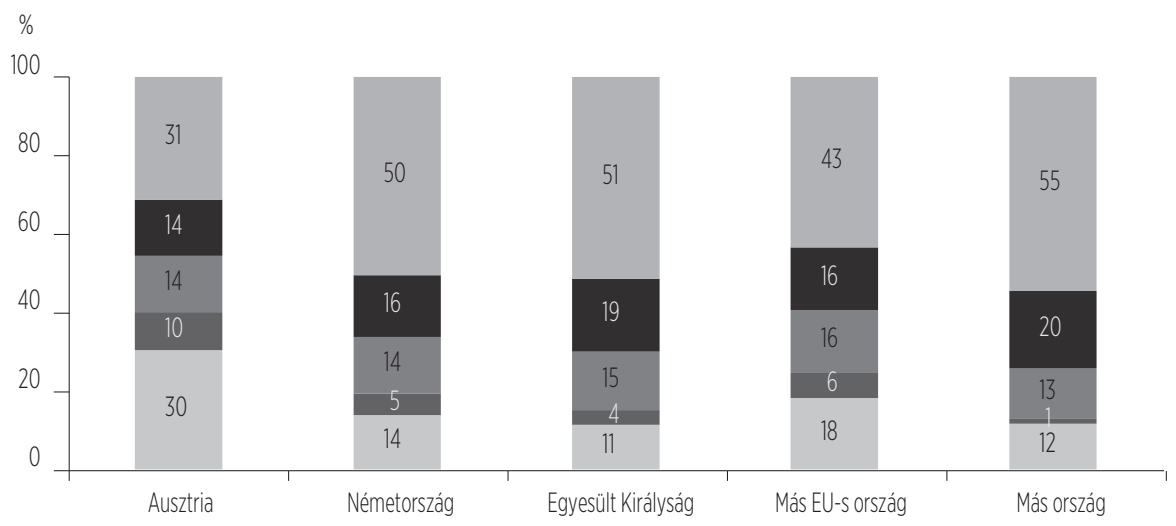

Egyszeri kivándorlás

— Legalább 5 évi külföldi tartózkodást követő egyszeri visszavándorlás

1-4 év külföldi tartózkodást követő egyszeri visszavándorlás

— évnél rövidebb külföldi tartózkodást követő egyszeri visszavándorlás

cirkuláris mobilitás 
A 2010 és 2013 között kivándoroltak visszatérésének intenzitása 2016-ig viszonylag egyenletesen alakult, ám ezt követően főként az Egyesült Királyság és a három fő célországon kívüli országokban élők esetében kissé felgyorsult (5. ábra). Jóllehet az évtized elején kivándorlók 2016-ot követő visszavándorlásait részben magyarázhatjuk a Brexitről szóló népszavazással, azonban az Egyesült Királyságon kívül élők esetében más hatásokról van szó.

5. ábra: A 2010-2013 között kivándoroltak létszámának alakulása az egyes célországokban

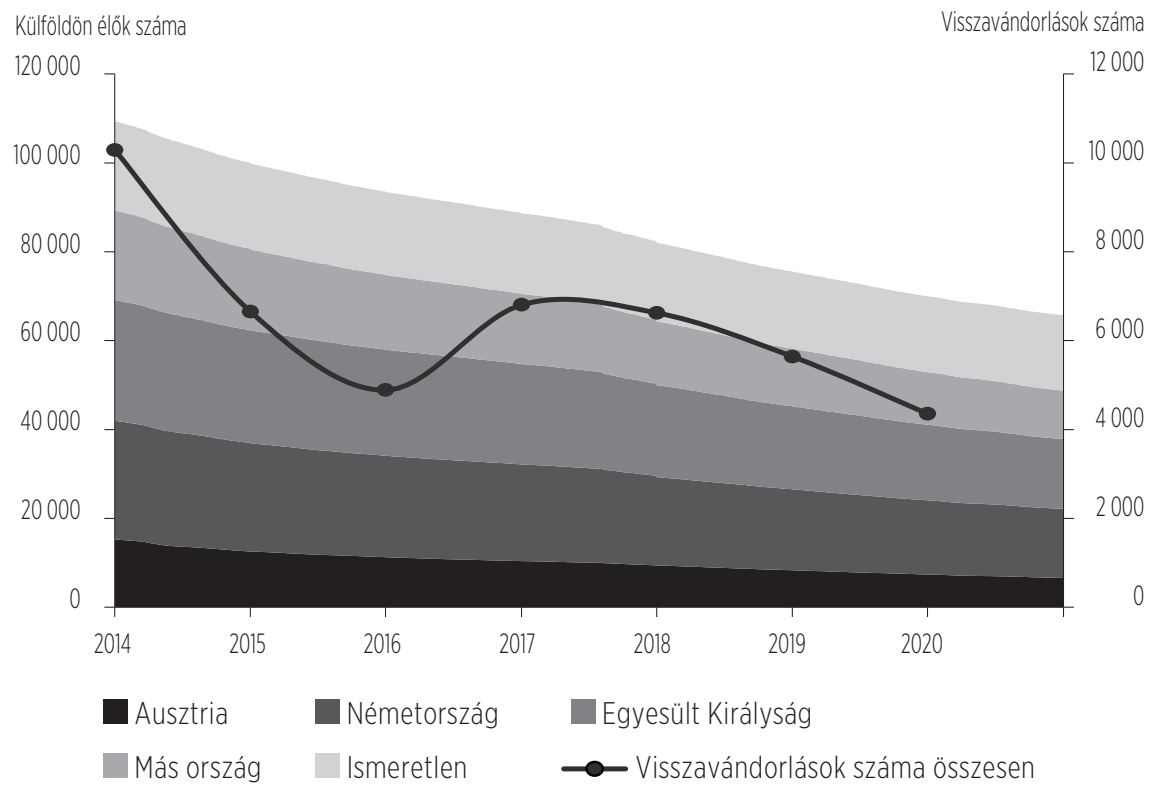

Forrás: saját szerkesztés a NEAK TAJ adatai alapján.

Az évtized elején kivándorlók viselkedését erőteljesen alakítják a csoport demográfiai jellemzői. Látható, hogy a nemi arányok csak azoknak az esetében kiegyenlítettek (50-50\%), akik az évtized eleji kivándorlásukat követően (még) nem tértek haza, a többi vándorlási mintázatban azonban az eltérő foglalkoztatási jellemzőknek köszönhetően nagyobb arányban vettek részt férfiak. Az egyszeri migrációt követően visszavándorlók körében a külföldön töltött időtől függetlenül 57-58\% a férfiak aránya, azonban a cirkuláris migránsok körében ennél alacsonyabb (52\%) (3. melléklet).

Mivel az ekkor kivándorlók háromnegyede a húszas-harmincas éveiben indult útnak, tehát életkori szempontból viszonylag homogénnek mondható, ezért ki- és visszavándorlási mintázataik is erőteljesen magyarázhatók az életciklus 
eseményeikkel. Bár a vizsgált adatok csak korlátozottan alkalmasak arra, hogy egész háztartások mozgásait vizsgáljuk," a rendelkezésre álló információk alapján is körvonalazódnak bizonyos jellegzetességek. Egyértelműen kirajzolódik, hogy az évtized elején kivándorolt családok magasabb arányban maradtak külföldön, mint az egyedül útnak indulók: azok a 30 évnél idősebb korcsoportokba tartozó személyek, akik háztartástagjaikkal együtt vándoroltak ki, más csoportoknál magasabb arányban (55\%) döntöttek úgy, hogy (legalábbis 2020-ig bezárólag) nem térnek haza. Ennél is árulkodóbb azonban, hogy a gyermekként kivándorlók - akik feltehetőleg szüleikkel együtt költöztek - 71\%-a még mindig külföldön él, eszerint a kivándorló gyermekes családok jellemzően új életet kezdtek külföldön. Ezzel szemben a háztartástagok nélkül kivándorló, idősebb (3140 és 40 év feletti) korcsoportokba tartozók mintázataiban nagyobb arányban figyelhetők meg átmeneti és ismétlődő mozgások, amely feltételezhetően időszakos külföldi munkavállalást jelent, amíg a háztartás többi tagja Magyarországon marad.

A hosszabb idejü, legalább 5 éven át tartó külföldi tartózkodást követő viszszavándorlás leginkább a fiatalabb, 18-24 éves és a 25-30 éves korcsoport tagjaira volt jellemző, főként azokra, akik háztartástagjaikkal (többségében partnerükkel) vándoroltak ki. Mivel a csoport tagjai közül sokaknál ez éppen a gyermekvállalási kort jelenti, feltételezhető, hogy ez is erőteljesen közrejátszik a visszavándorlási döntésben. Láthattuk azonban, hogy a két idősebb korcsoport esetében a partnerrel vagy családtaggal együtt vándorlás a hosszú távú külföldi letelepedés irányába hat, addig a húszas éveikben, főként a 25-30 évesen kivándorlók esetében ez éppen fordítva történik, vagyis az egyedül kivándorlók nagyobb arányban maradtak külföldön (47\%), mint azok, akik párjukkal vagy más háztartástaggal költöztek ki (42\%). Feltételezhető, hogy a csoport egy része külföldön talált partnert (6. ábra).

\footnotetext{
"Az elemzéshez használt állományok tartalmaznak állandó és ideiglenes lakcímet, így az egy lakcímre bejegyzett személyek összekapcsolhatók. Ez azonban nem feltétlenül jelenti, hogy az adott személyek valóban ezen a címen élnek és az sem állitható biztosan, hogy valóban egy háztartáshoz tartoznak. A lakcimek összekapcsolása segítségével előállított háztartási azonositó minőségét mutatja, hogy az adatállományokban regisztrált 0-17 éves kivándorló gyermekek háromnegyedét sikerült lakcimük alapján összekapcsolni egy másik kivándorlóval. Feltételezhetỏ, hogy a gyermekek túlnyomó része nem egyedül, hanem családtaggal vándorolt külföldre, látható, hogy a háztartási szintủ következtetéseket óvatossággal kell kezelnünk. Az adatok emellett tartalmaznak információt a családi állapotról is, azonban mindig csak a legutolsó regisztráltállapotra vonatkozóan, így az évtized elején kivándorlók esetében félrevezetỏ volna ennek vizsgálata.
} 
6. ábra: 2010-2013 között a háztartástagjukkal és háztartástagjuk nélkül kivándorlók mobilitási mintázatai életkori csoportok szerint

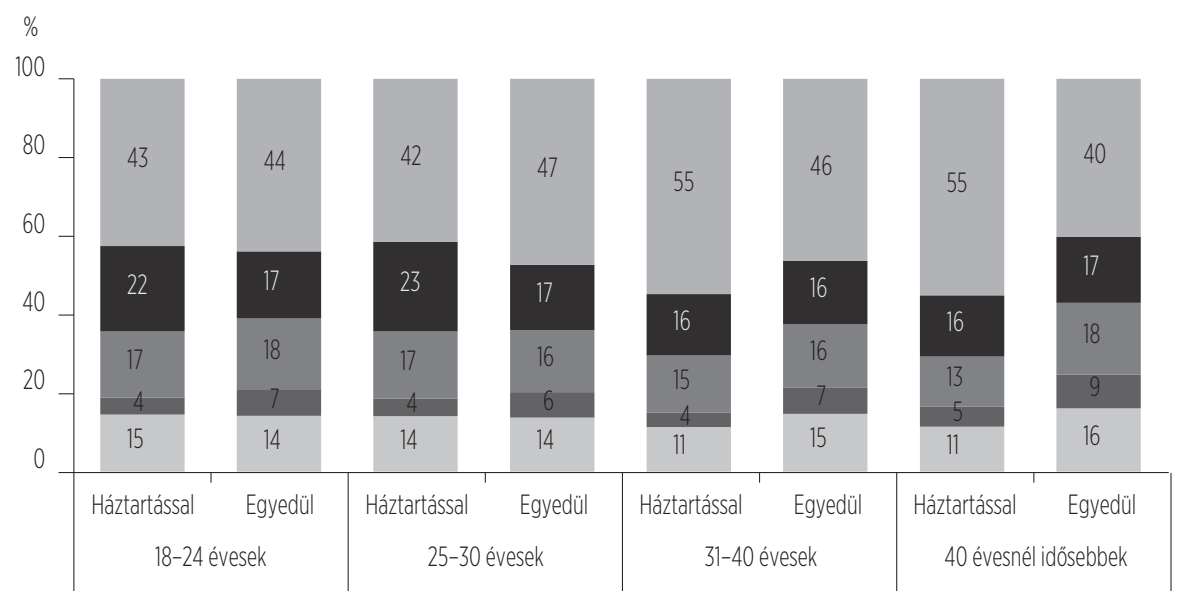

Egyszeri kivándorlás

Legalább 5 évi külföldi tartózkodást követő egyszeri visszavándorlás

1-4 év külföldi tartózkodást követő egyszeri visszavándorlás

— évnél rövidebb külföldi tartózkodást követő egyszeri visszavándorlás

Cirkuláris mobilitás

Forrás: saját szerkesztés a NEAK TAJ adatai alapján. N=106 284

Az adatok által jól körvonalazódik az évtized elején kivándorlók két különböző migrációs stratégiája: az időszakos, Magyarországgal szorosabb köteléket fenntartó munkamigráció, melyben jellemzően csak a háztartás egyik tagja vesz részt, valamint az olyan hosszabb távú kivándorlás, melynek során teljes háztartások hagyják el Magyarországot. Míg előbbi nagyobb arányban jellemző a férfiakra és a szakmunkásokra, addig az utóbbi sokkal inkább a felsőfokú végzettségüek körében kiemelkedő és esetében a nemi arányok is kiegyenlítettebbek (Blaskó és Gödri, 2014). 


\section{A HAZATÉRÉS KORSZAKA? AZ ELMÚLT ÉVEK VISSZAVÁNDORLÁSI HULLÁMÁNAK LEHETSÉGES MAGYARÁZATAI}

Az utóbbi években mind a hazai adatok, mind a tükörstatisztikák alapján egyre világosabban körvonalazódik a kivándorlási kedv csökkenése és a visszavándorlások intenzitásának növekedése (KSH, 2021; Gödri, 2018). Mivel egy egészen új jelenségről van szó, amelyet a korábbi kutatások sem jeleztek előre, a közelmúlt visszavándorlásainak összetétele és a mögötte húzódó okok kevéssé ismertek.

Fontos azonban szem előtt tartani, hogy bár a kivándorlások csökkenése időben egybeesik a visszavándorlások növekedésével, a két jelenség mögött eltérő okok és mechanizmusok is állhatnak. Amennyiben a cirkuláció aránya tartósan magas, az párhuzamosan a ki- és visszavándorlások számát is folyamatosan emelheti. Ha azonban a hosszabb távú külföldi tartózkodásokat követő visszavándorlások is jelentősek, akkor a jelenlegi visszavándorlási hullám leginkább az évtized elején tapasztalható növekvő kivándorlásokkal függ össze. Könnyen belátható, hogy jelentős mennyiségü visszavándorlásra csak abban az esetben számíthatunk, ha elegen élnek külföldön olyanok, akik közül a visszavándorlók szelektálódhatnak. Mivel a 2010-es évek előtt a kivándorlások száma messze elmarad a 2010-2015 között tapasztalttól, szükségszerüen a visszavándorlások száma is alacsonyabb volt az évtized első felében. Az ekkor tapasztalt intenzív kivándorlások azonban egy olyan külföldön élő „tartalékot” képeztek, amely az évtized végére már a tartósan letelepedők köréből is képes biztosítani a folyamatos visszaáramlásokat.

Látható azonban, hogy a 2018 és 2020 között visszavándorlók körében valóban jelentős (30\%) azoknak az aránya, akik legalább 5 év külföldi tartózkodást követően tértek haza (vagyis az évtized első felében vándoroltak ki). Ugyanakkor az évtized elejéhez viszonyítva a rövid távú és cirkuláris formák aránya is megnőtt, ezért figyelmet kell fordítanunk e két mintázat összetett hatásaira is (7. ábra).

Bár a célország társadalmába és munkaerő-piacába való integráció előrehaladtával a kivándorlók hazatérési esélye egyre kisebb (OECD, 2008), az évtized elején kivándorlók példáján keresztül láthattuk, hogy a visszavándorlások intenzitása nem feltétlenül alakul egyenletesen. A 2010 és 2013 között kivándorolt magyarok ugyan valóban nagyobb eséllyel tértek vissza a kivándorlást követően közvetlenül, azonban a visszavándorlások 4-6 évi külföldi tartózkodást követően valamelyest megugrottak. A vizsgált csoport esetében ez jelentős részben 2016 utánra tehető, ezért a jelenségben éppúgy közrejátszhatnak a ki- 
bocsátó és a fogadó országokban tapasztalható politikai, gazdasági és társadalmi változások, mint a visszavándorlók életciklusához köthető események és egyéni döntések.

\section{7. ábra: A 2018-2020 között visszavándorlók mobilitási mintázatai}

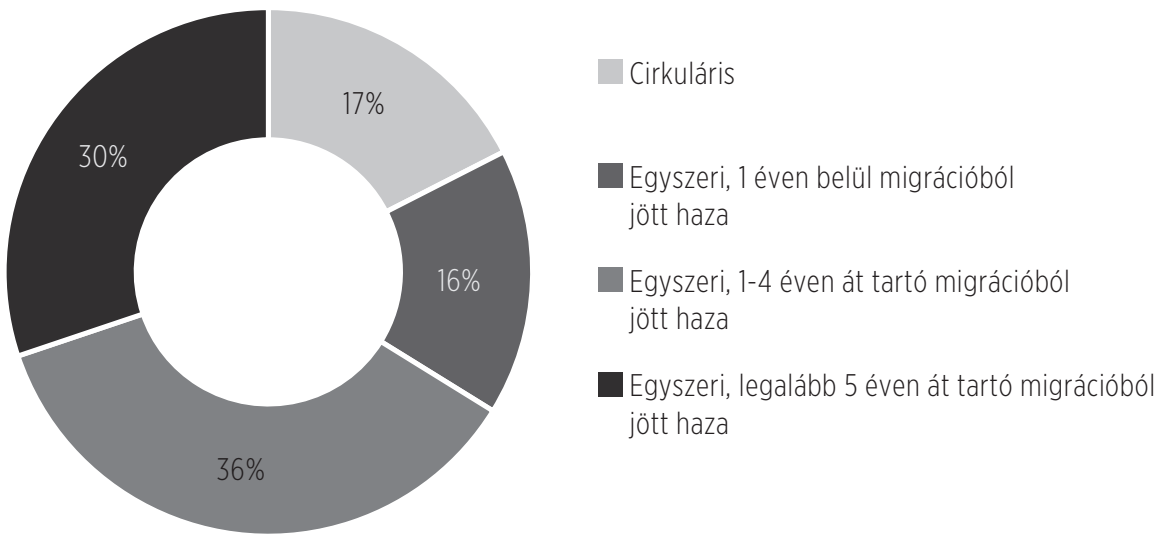

Forrás: saját szerkesztés a NEAK TAJ adatai alapján. N=82 280

Bár a küldő és fogadó országok gazdasági fejlettsége közötti nagyobb eltérés a visszavándorlások ellenébe hat (OECD, 2008), az Európai Unión belüli gazdasági különbségek az évtized során viszonylag tartósnak bizonyultak, így nem magyarázzák egyértelműen a visszavándorlások növekvő számát. Az is feltételezhető azonban, hogy a fogadó országokban tapasztalható recessziók jobban sújtják a bevándorlókat, mint a helyi lakosságot, ezért a kisebb mértékü gazdasági visszaesések is jelentősen ösztönözhetik a visszavándorlásokat (Bijwaard and Wahba, 2014).

A fogadó országok évtized során tapasztalható gazdasági és politikai változásai közül elsősorban az Egyesült Királyságban zajló eseményeket érdemes megvizsgálni. Látható, hogy az Egyesült Királyság Európai Unióból való kilépése és az erről döntő népszavazás ugyan érzékelhető hatással volt az itt élők viszszavándorlására, de a 2016-ot követően intenzívebbé váló hazatéréseket csak kisebb részben magyarázza a Brexit. 2017-ben és 2018-ban a visszavándorlók körében valamivel magasabb arányban találunk angliai visszavándorlókat, mint más években, továbbá az Egyesült Királyságból hazatérők száma is nőtt. Azonban 2016-ot követően más országokból egyaránt jelentősen emelkedtek a visszaáramlások (8. ábra). Általánosságban elmondható, hogy az Egyesült 
Királyságban hosszabb időt tartózkodtak a magyar kivándorlók, mint más fogadó országban, de a legalább 5 éve külföldön élők hazatérése a Brexit népszavazást követő években sem emelkedett jelentős mértékben.

Ugyan a Brexit mellett az évtized utolsó évében a koronavírus megjelenése is nagyban alakíthatta a trendeket, azonban ennek következményeit igazán csak később, néhány év távlatából vizsgálhatjuk meg átfogóan. Jelenleg viszont úgy tűnik, hogy egyedül az Ausztriából hazatérők száma növekedett jelentős mértékben 2020-ban.

\section{8. ábra: A visszavándorlások számának alakulása a föbb célországok szerint²}

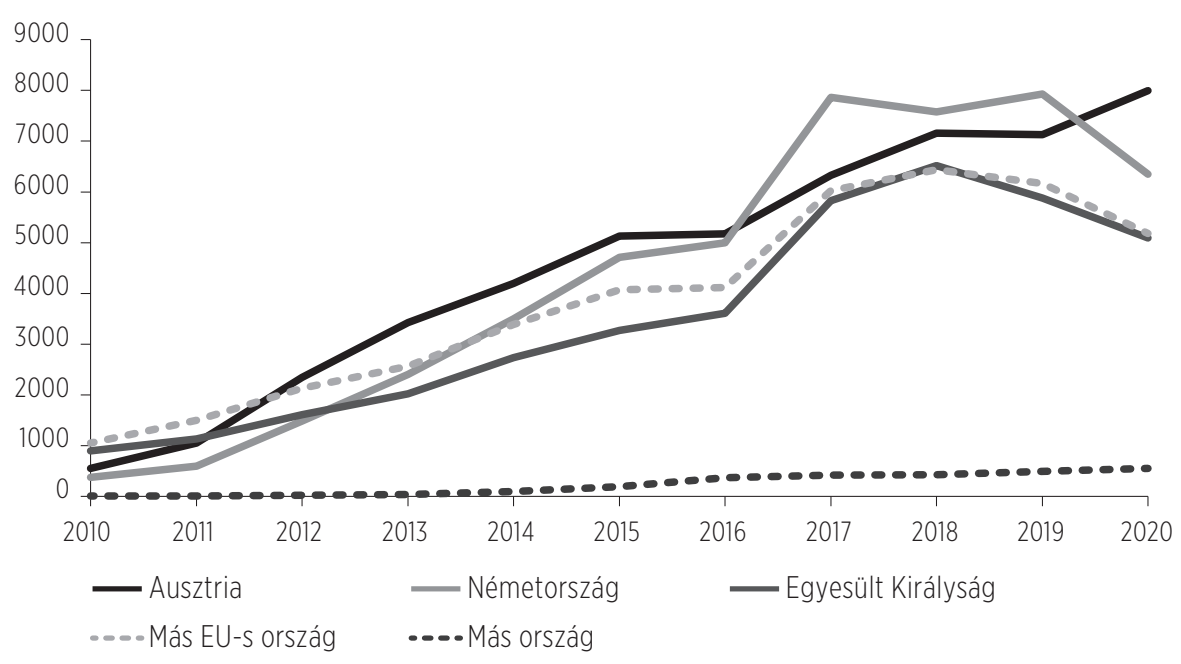

Forrás: saját szerkesztés a NEAK TAJ adatai alapján.

A fogadó országokhoz viszonyítva azonban a küldő országok gazdasági-politikai környezete sokkal jelentősebb hatással lehet a visszavándorlások alakulására (Papademetriou and Terrazas, 2009; Martin and Radu, 2012). Az elemzés során felhasznált adatok sajnos nem teszik lehetővé, hogy ezekre vonatkozóan vonhassunk le következtetéseket. Azonban további kutatások során, más adatforrások alapján érdemes volna például a magyarországi bérek alakulásának vagy akár a családpolitikai támogatások bevezetésének hatásait megvizsgálni a visszavándorlások alakulására nézve.

\footnotetext{
${ }^{12}$ A visszavándorlók 8\%-a esetében a külföldi tartózkodás országa ismeretlen.
} 
Korábbi kutatások alapján arra következtethetünk, hogy mikroszinten vizsgálva a külföldön töltött idő és a jövedelem U-alakú kapcsolatban áll egymással, amellett, hogy az alacsonyabb jövedelmű csoportok esetében a legmagasabb a visszavándorlás esélye (Klinthäll, 2013; Bijwaard and Wahba, 2014). Ez arra mutat rá, hogy a visszavándorlást magyarázó két gazdasági motivációkkal foglalkozó irányzat vegyesen van jelen a visszavándorlások során. Abban az esetben, ha a visszavándorlás elöre tervezett egy bizonyos céljövedelem elérését követően, a visszavándorlók a magasabb jövedelmű csoportokból kerülnek ki. Ha azonban a visszavándorlás a kivándorlási döntés kudarcának következménye, a visszavándorlók alacsonyabb jövedelemmel térnek haza (Borjas and Braatsberg, 1996). Bár a NEAK TAJ adatai nem tartalmaznak információkat a jövedelemre vonatkozóan, a visszavándorláskor regisztrált gazdasági aktivitás alapján feltételezhetjük, hogy a magasabb végzettségű és jövedelmű kivándorlók valóban hosszabb ideig maradnak külföldön. Ameddig az egy éven belül hazatérők 27\%-a dolgozott a visszavándorlást követően felsőfokú végzettséget igénylő vagy irodai foglalkozásokban, addig ez az arány az 1-4 évet követően visszavándorlók esetében 36\%, a legalább 5 év után visszavándorlók esetében pedig 45\%. Jelentős különbségeket figyelhetünk meg ellenben nemek szerint: a nők körében jóval magasabb a szellemi foglalkozásúak és a szolgáltatói szektorban dolgozók aránya, míg a férfiak esetében jelentősebb az ipari szektor (9. ábra).

Az elvándorlásokhoz hasonlóan a legtöbb elemzés a visszavándorlás jelenségét is főként gazdasági tényezőkkel magyarázza, de a hazatérések esetében érdemes külön figyelmet szentelni az egyéni okoknak és a családi kapcsolatok szerepének is. Az évtized elején, 2010-2013 között kivándorlók esetében már korábban láthattuk, hogy a tartós migrációra és visszavándorlásra vonatkozó döntést nagymértékben befolyásolhatja az életkor együttes hatása azzal, hogy a vándorlók családtagjaikkal, háztartástagjaikkal együtt költöznek-e a külföldre. Számos kérdőíves felmérés jutott arra a következtetésre, hogy ameddig a kivándorlást elsődlegesen a magasabb jövedelmek motiválják, addig a visszavándorlási döntésben jóval nagyobb súlya van a családi okoknak és más szociális kapcsolatoknak (Martin and Radu, 2012; Horváth, 2016; KSH, 2018). 
9. ábra: A 2018 és 2020 között visszavándorlók gazdasági aktivitása nemek és mobilitási mintázatok szerint

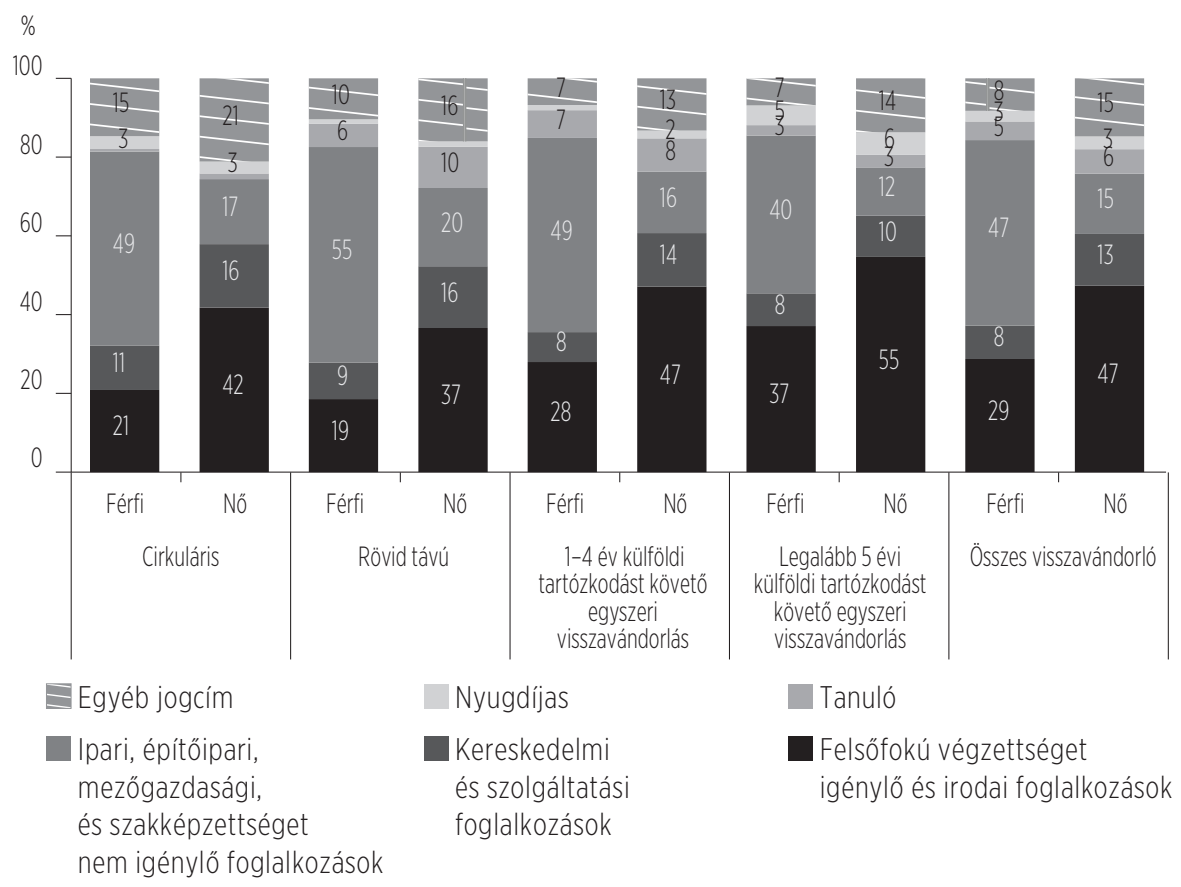

Forrás: saját szerkesztés a NEAK TAJ adatai alapján. N=43 124

\section{ÖSSZEGZÉS}

A 2010-es évek migrációs folyamataiban megfigyelhető változások közül az egyik legszembetűnőbb a rövid távú és ismétlődő mobilitási formák fokozatos térnyerése, amely leginkább az idősebb korcsoportok, valamint az ipari és vendéglátói szektorban dolgozók időszakos munkavállalási stratégiájává vált. A visszavándorlók körében azonban az évtized második felétől jelentőssé vált a hosszú távú, legalább 5 évi külföldi tartózkodást követően hazatérők aránya is. Utóbbi jelenség összekapcsolódik az évtized eleji európai munkaerő-piaci nyitások következtében megugró kivándorlásokkal.

Az évtized elején kivándorló magyarok fele 2020-ig bezárólag (még) nem tért haza. A tartós letelepedés és a visszavándorlás időzítése szintén erőteljesen összekapcsolódik a csoport életciklus-eseményeivel. Ameddig a 30 éven felüliek esetében a partnerrel vagy családtaggal együtt vándorlás a hosszú 
távú külföldi letelepedés irányába hatott (amely kiemelten igaz a gyermekes családokra), addig a húszas éveikben kivándorlók esetében ez éppen fordított volt, vagyis az egyedül kivándorlók nagyobb arányban maradtak külföldön.

A 2010-es évek elején megfigyelhető kivándorlási hullám által a külföldön élő magyarok csoportja korábban nem látott méretüre nőtt, amely az évtized második felétől lehetővé tette a folyamatos visszavándorlásokat a hosszabb idő óta külföldön élők köréből is. Ezáltal a 2016-ot követően egyre intenzívebbé váló visszavándorlásban éppúgy megtalálhatóak a rövid távú és cirkuláris formák, mint a hosszabb idejủ migrációs tapasztalatot követő hazatérések. Az Egyesültt Királyság kilépése az Európai Unióból érzékelhető hatással volt az angliai visszavándorlásokra, noha a 2016-ot követően intenzívebbé váló hazatéréseket csak kisebb részben magyarázza a Brexit.

Bár az évtized elején még az Egyesült Királyság jelentette a magyar kivándorlók egyik legfőbb célországát, mára az ország jelentősége nagymértékben visszaszorult az új kivándorlók körében. Amellett, hogy napjainkban a korábban angliai kivándorlások jelentős része Ausztria felé irányul, a rövid távú és cirkuláris mobilitási formák jelentőségének növekedése is hozzájárult Ausztria szerepének megerősödéséhez. Az évtized során így a kivándorlók három fő célországa gyakorlatilag két fő célországra, Németországra és Ausztriára szükült. 


\section{MELLÉKLETEK}

1. melléklet: A rövid távú (legalább 3 hónapos, de 12 hónapnál rövidebb) külföldi tartózkodások megoszlása föbb célországok szerint, 2010-2019

\begin{tabular}{ccccccc}
$\begin{array}{c}\text { Kivándorlás } \\
\text { éve }\end{array}$ & Ausztria & Németország & $\begin{array}{c}\text { Egyesült } \\
\text { Királyság }\end{array}$ & $\begin{array}{c}\text { Más EU-s } \\
\text { ország }\end{array}$ & Más ország & Összesen \\
\hline 2010 & $33 \%$ & $12 \%$ & $21 \%$ & $33 \%$ & $0 \%$ & $100 \%$ \\
2011 & $42 \%$ & $19 \%$ & $14 \%$ & $25 \%$ & $0 \%$ & $100 \%$ \\
2012 & $40 \%$ & $25 \%$ & $14 \%$ & $21 \%$ & $0 \%$ & $100 \%$ \\
2013 & $40 \%$ & $24 \%$ & $13 \%$ & $22 \%$ & $0 \%$ & $100 \%$ \\
2014 & $40 \%$ & $27 \%$ & $11 \%$ & $21 \%$ & $0 \%$ & $100 \%$ \\
2015 & $39 \%$ & $29 \%$ & $11 \%$ & $21 \%$ & $1 \%$ & $100 \%$ \\
2016 & $40 \%$ & $27 \%$ & $11 \%$ & $20 \%$ & $1 \%$ & $100 \%$ \\
2017 & $41 \%$ & $27 \%$ & $8 \%$ & $22 \%$ & $1 \%$ & $100 \%$ \\
2018 & $44 \%$ & $26 \%$ & $8 \%$ & $21 \%$ & $1 \%$ & $100 \%$ \\
2019 & $49 \%$ & $21 \%$ & $7 \%$ & $21 \%$ & $2 \%$ & $100 \%$ \\
\hline
\end{tabular}

Forrás: saját szerkesztés a NEAK TAJ adatai alapján. N=61 612

2. melléklet: A rövid távú (legalább 3 hónapos, de 12 hónapnál rövidebb) külföldi tartózkodások megoszlása korcsoportok szerint, 2010-2019

\begin{tabular}{|c|c|c|c|c|c|c|}
\hline $\begin{array}{l}\text { Kivándorlás } \\
\text { éve }\end{array}$ & $\begin{array}{c}0-17 \\
\text { évesek }\end{array}$ & $\begin{array}{l}\text { 18-24 } \\
\text { évesek }\end{array}$ & $\begin{array}{l}\text { 25-30 } \\
\text { évesek }\end{array}$ & $\begin{array}{l}\text { 31-40 } \\
\text { évesek }\end{array}$ & $\begin{array}{l}40 \text { évesnél } \\
\text { idősebbek }\end{array}$ & Összesen \\
\hline 2010 & $0 \%$ & $20 \%$ & $35 \%$ & $30 \%$ & $14 \%$ & $100 \%$ \\
\hline 2011 & $1 \%$ & $18 \%$ & $29 \%$ & $31 \%$ & $21 \%$ & $100 \%$ \\
\hline 2012 & $1 \%$ & $18 \%$ & $29 \%$ & $29 \%$ & $23 \%$ & $100 \%$ \\
\hline 2013 & $1 \%$ & $19 \%$ & $27 \%$ & $29 \%$ & $24 \%$ & $100 \%$ \\
\hline 2014 & $1 \%$ & $20 \%$ & $26 \%$ & $28 \%$ & $25 \%$ & $100 \%$ \\
\hline 2015 & $1 \%$ & $20 \%$ & $25 \%$ & $28 \%$ & $26 \%$ & $100 \%$ \\
\hline 2016 & $2 \%$ & $20 \%$ & $24 \%$ & $26 \%$ & $28 \%$ & $100 \%$ \\
\hline 2017 & $2 \%$ & $20 \%$ & $23 \%$ & $24 \%$ & $30 \%$ & $100 \%$ \\
\hline 2018 & $2 \%$ & $20 \%$ & $23 \%$ & $23 \%$ & $32 \%$ & $100 \%$ \\
\hline 2019 & $1 \%$ & $20 \%$ & $24 \%$ & $23 \%$ & $32 \%$ & $100 \%$ \\
\hline
\end{tabular}

Forrás: saját szerkesztés a NEAK TAJ adatai alapján. ( $N=65$ 897) 
3. melléklet: A 2010-2013 között kivándorlók mobilitási mintázatai nemek és korcsoportok szerint

\begin{tabular}{|c|c|c|c|c|c|}
\hline & $\begin{array}{c}\text { Egyszeri } \\
\text { kivándorlás }\end{array}$ & $\begin{array}{l}\text { Cirkuláris } \\
\text { mobilitás }\end{array}$ & $\begin{array}{c}1 \text { évnél } \\
\text { rövidebb } \\
\text { külföldi } \\
\text { tartózkodást } \\
\text { követő } \\
\text { egyszeri } \\
\text { vissza- } \\
\text { vándorlás }\end{array}$ & $\begin{array}{l}\text { 1-4 év } \\
\text { külföldi } \\
\text { tartózkodást } \\
\text { követő } \\
\text { egyszeri } \\
\text { vissza- } \\
\text { vándorlás }\end{array}$ & $\begin{array}{c}\text { Legalább } \\
5 \text { évi külföldi } \\
\text { tartózkodást } \\
\text { követő } \\
\text { egyszeri } \\
\text { vissza- } \\
\text { vándorlás }\end{array}$ \\
\hline 0-17 évesek & $4 \%$ & $1 \%$ & $1 \%$ & $2 \%$ & $2 \%$ \\
\hline 18-24 évesek & $17 \%$ & $18 \%$ & $19 \%$ & $22 \%$ & $21 \%$ \\
\hline 25-30 évesek & $26 \%$ & $28 \%$ & $27 \%$ & $27 \%$ & $29 \%$ \\
\hline 31-40 évesek & $32 \%$ & $32 \%$ & $28 \%$ & $28 \%$ & $28 \%$ \\
\hline 40 évesnél idősebbek & $21 \%$ & $21 \%$ & $25 \%$ & $21 \%$ & $19 \%$ \\
\hline Összesen & $100 \%$ & $100 \%$ & $100 \%$ & $100 \%$ & $100 \%$ \\
\hline Férfi & $50 \%$ & $52 \%$ & $57 \%$ & $58 \%$ & $58 \%$ \\
\hline Nő & $50 \%$ & $48 \%$ & $43 \%$ & $42 \%$ & $42 \%$ \\
\hline Összesen & $100 \%$ & $100 \%$ & $100 \%$ & $100 \%$ & $100 \%$ \\
\hline
\end{tabular}

Forrás: saját szerkesztés a NEAK TAJ adatai alapján. N=127 710

4. melléklet: A 2018-2020 között visszavándorlók mobilitási mintázatai nemek és korcsoportok szerint

\begin{tabular}{lcccc} 
& $\begin{array}{c}\text { 1 évnél rövidebb } \\
\text { külföldi } \\
\text { tartózkodást } \\
\text { követő egyszeri } \\
\text { visszavándorlás }\end{array}$ & $\begin{array}{c}\text { 1-4 év külföldi } \\
\text { tartózkodást } \\
\text { követő egyszeri } \\
\text { visszavándorlás }\end{array}$ & $\begin{array}{c}\text { Legalább } \\
5 \text { évi külföldi } \\
\text { tartózkodást } \\
\text { követő egyszeri } \\
\text { visszavándorlás }\end{array}$ \\
\hline 0-17 évesek & $1 \%$ & $3 \%$ & $4 \%$ & $4 \%$ \\
$18-24$ évesek & $13 \%$ & $25 \%$ & $25 \%$ & $22 \%$ \\
$25-30$ évesek & $26 \%$ & $22 \%$ & $25 \%$ & $30 \%$ \\
$31-40$ évesek & $29 \%$ & $20 \%$ & $23 \%$ & $26 \%$ \\
40 évesnél idősebbek & $31 \%$ & $31 \%$ & $23 \%$ & $18 \%$ \\
Összesen & $100 \%$ & $100 \%$ & $100 \%$ & $100 \%$ \\
Férfi & $55 \%$ & $58 \%$ & $59 \%$ & $58 \%$ \\
Nő & $45 \%$ & $42 \%$ & $41 \%$ & $42 \%$ \\
Összesen & $100 \%$ & $100 \%$ & $100 \%$ & $100 \%$
\end{tabular}

Forrás: saját szerkesztés a NEAK TAJ adatai alapján. N=82 280 


\section{IRODALOM}

Agunias, D. R. (2006). From a Zero-Sum to A Win-Win Scenario? Literature Review on Circular Migration. Washington, D.C: Migration Policy Institute.

Bálint L., Csányi Z., Farkas M., Hluchány H. és Kincses Á. (2017). International migration and official migration statistics in Hungary. Regional Statistics, 7(2), 101-123.

Bijwaard, G. and Wahba, J. (2014). Do High-Income or Low-Income Immigrants Leave Faster? Journal of Development Economics, 108, 54-68.

Blaskó Zs. és Gödri I. (2014). Kivándorlás Magyarországról: Szelekció és célország-választás az „új migránsok” körében. Demográfia, 57(4), 271-307.

Borjas, G. J. and Bratsberg, B. (1996). Who leaves? The Outmigration of the Foreign-born. The Review of Economics and Statistics, 78(1), 165-176.

Csányi Z., Ligeti A. S., Novák J., Urbán F., Zöldi L (2021). A nemzetközi vándorlás fogalma és mérése a hazai hivatalos statisztikában. Demográfia, 64(1), 79-102.

de Haas, H., Castles, S. and Miller, M. J. (2020). The Age of Migration. 6th Edition. International Population Movements in the Modern World. London: Red Globe Press, Macmillan International Higher Education.

Engbersen, G. and Snel, E. (2013). Liquid migration. Dynamic and fluid patterns of postaccession migration flows. In Glorius, B., Grabowska-Lusinska, I., and Kuvik, A. (eds.), Mobility in Transition. Migration Patterns after EU Enlargement. IMISCOE Research. Amsterdam: Amsterdam University Press.

Eurostat (2019). Metadata: Population (national level) (demo_pop). Elérhető: https://ec.europa.eu/eurostat/cache/metadata/en/demo_pop_esms.htm

Gödri I. (2018). Nemzetközi vándorlás. In Monostori J., Őri P. és Spéder Zs. (szerk.): Demográfiai portré 2018. Jelentés a magyar népesség helyzetéről. Budapest: KSH Népességtudományi Kutatóintézet.

Hárs Á. (2018). Növekvő elvándorlás: Lehetőségek, remények, munkaerő-piaci kilátások. In Kolosi T. és Tóth I. Gy. (szerk.): Társadalmi Riport 2018. Budapest: TÁRKI.

Hárs Á. (2020). Elvándorlás, visszavándorlás, bevándorlás. Jelenségek és munkaerőpiaci hatások. In Kolosi T., Szelényi, I. és Tóth, I. Gy. (szerk.): Társadalmi Riport 2020. Budapest: TÁRKI.

Horváth Á. (2016). Visszatérő kivándorlók. In Blaskó Zs. (szerk.): Közelkép. Nemzetközi vándorlás. Budapest: MTA Közgazdasági-és Regionális Tudományi Kutatóközpont.

Klinthall, M. (2013). Older Immigrants Leaving Sweden. In Percival, J (eds.): Return Migration in Later Life: International perspectives. Bristol: Policy Press at the University of Bristol.

Központi Statisztikai Hivatal [KSH] (2018). Mikrocenzus 2016. 10. Nemzetközi Vándorlás. Budapest: Központi Statisztikai Hivatal.

Központi Statisztikai Hivatal [KSH] (2021). Demográfiai Évkönyv, 2020. Budapest: Központi Statisztikai Hivatal.

Martin, R. and Radu, D. (2012). Return Migration: The Experience of Eastern Europe. International Migration, 50(6), 109-128.

Melegh A. (2011). Globalizáció és migráció Magyarországon. Educatio, 2011/2, 206-219. 
Monti, A., Drefahl, S., Mussino, E. and Härkönen, J. (2019). Over-coverage in population registers leads to bias in demographic estimates. Population Studies, 74(3), 451-469.

Moreh, C. (2014). Magyar bevándorlók az Egyesült Királyságban: Demográfiai, földrajzi és szociológiai körkép. Demográfia, 57(4), 309-343.

Organisation for Economic Co-operation and Development [OECD] (2008). Return Migration: A New Perspective. International Migration Outlook. Paris: OECD.

Papademetriou, D. G. and Terrazas, A. (2009). Immigrants and the Current Economic Crisis: Research Evidence, Policy Challenges, and Implications. Washington, DC: Migration Policy Institute.

Triandafyllidou, A. (2013). Circular migration: introductory remarks. In Triandafyllidou, A. (eds.), Circular Migration between Europe \& Its Neighbourhood. Choice or Necessity? Oxford: Oxford University Press.

United Nations [UN] (1998). Recommendations on Statistics of International Migration. Revision 1. New York: United Nations.

United Nations Economic Commission for Europe [UNECE] (2016). Defining and Measuring Circular Migration. New York and Geneva: United Nations Economic Commission for Europe.

United Nations Economic Commission for Europe [UNECE] (2018). Measuring International Labour Mobility. New York and Geneva: United Nations Economic Commission for Europe.

United Nations Economic Commission for Europe [UNECE] (2020). Guidance on the use of longitudinal data for migration statistics. Geneva: United Nations Economic Commission for Europe.

Willekens, F. (2019). Evidence-Based Monitoring of International Migration Flows in Europe. Journal of Official Statistics, 35(1), 231-277. 


\section{CHANGING PATTERNS OF GEOGRAPHICAL MOBILITY: TEMPORARY EMIGRATION, PERMANENT SETTLEMENT AND CIRCULAR MIGRATION AMONG HUNGARIAN CITITENS}

\section{ABSTRACT}

Migration statistics describing geographical mobility as a one-way, permanent process are not fully appropriate anymore to keep up with the rapidly changing global trends in the aftermath of the Millennium. However, from a longitudinal perspective on the administrative data - originally used to measure settlingpurposed emigration and return migration of Hungarians - tracing back their migration history becomes possible, that lets us identify circular movements and measure durations of stay. In accordance with the data on Hungarian citizens, their mobility patterns since the 2010s have been characterized by both shorter and longer terms movements. Over the past decade, short-term and repeated migratory movements have become increasingly prominent among Hungarian migrants, which indicates that ,liquid' migration patterns are gaining ground, especially among temporary workers in the industrial and service sectors. Half of those who emigrated at the beginning of the last decade have not yet returned. Since the size of emigrant stocks has been continuously increasing, a greater pool of potential returners have come to exist that include also those living abroad for longer periods. At the same time, by the end of the 2010s, Great-Britain had lost much of its attractiveness, so that only Germany and Austria are considered today as the main destinations for Hungarian migrants. 